УДК $343.74+343.71$

Шинкевич М.В.

К ВОПРОСУ О ПРЕДМЕТЕ ПРИСВОЕНИЯ ИЛИ РАСТРАТЫ, СОВЕРШЕННЫЕ ЛИЦОМ, С ИСПОЛЬЗОВАНИЕМ СВОЕГО СЛУХЕБНОГО ПОЛОЖЕНИЯ

Shinkevich M.V.

\title{
TO THE QUESTION OF THE SUBJECT \\ OF EMBEZZLEMENT OR EMBEZZLEMENT COMMITTED BY A PERSON USING HIS OFFICIAL POSITION
}

В статье обращается внимание, что такой признак состава преступления как предмет преступления, выступает «своеобразным эталоном». Именно предмет преступления обладает присущими ему юридическими свойствами конкретного состава преступления.

Важное значение для квалификации присвоения или растраты имеют характеристики предмета преступления, как общие, так и специальные, определяющие специфику этих форм хищения и устанавливаемые законодателем через указание на вверенность чужого имущества виновному.

Сделан вывод о том, что при определении предмета присвоения или растраты следует понимать имущество более широко, выходя за рамки отнесения к нему только вещей и признавая возможность хищения иного имущества.

Ключевые слова: присвоение, растрата, хищение, чужое имущество, предмет хищения, имущество вверенное виновному, правомерность владения, цифровые права, безналичные денежные средства.

The article notes attention to the fact that such a sign of the composition of the crime as the subject of the crime acts as a "kind of standard". It is the subject of the crime that has the inherent legal properties of a specific corpus delicti. Important for the qualification of embezzlement or embezzlement are the characteristics of the subject of the crime, both general and special, which determine the specifics of these forms of theft and are established by the legislator through an indication of the entrustment of someone else's property to the perpetrator. It is concluded that when determining the subject of appropriation or embezzlement, property should be understood more broadly, going beyond the attribution of only things to it and recognizing the possibility of theft of other property.

Keywords: assignment, embezzlement, misappropriation, someone else's property, the object of theft, property entrusted to the guilty person, legality of ownership, digital rights, non-cash funds.

Говоря о присвоении или растрате обязательным признаком состава преступления является как раз предмет, который законодательно определен, как имущество, вверенное виновному. Верховный Суд РФ в п. 23 постановления Пленума Верховного Суда РФ от 30.11.2017 № 48 «О судебной практике по делам о мошенничестве, присвоении и растрате» отметил, что деяние может быть квалифицировано как присвоение или растрата лишь при условии, что похищенное имущество находилось в правомерном владении либо ведении этого лица, которое в силу должностного или иного служебного положения, договора либо специального поручения осуществляло полномочия по распоряжению, 
управлению, доставке, пользованию или хранению в отношении чужого имущества.

Что касается правомерности владения, а также причинения ущерба законному владельцу, то данные признаки целесообразнее рассмотреть в рамках анализа объекта указанного состава.

Важное значение для квалификации присвоения или растраты имеют характеристики предмета преступления, как общие, относящиеся в целом ко всем признакам предмета преступных посягательств на отношения собственности, так и специальные, определяющие специфику этих форм хищения и устанавливаемые законодателем через указание на вверенность чужого имущества виновному.

Приведенное выше разъяснение Пленума Верховного суда РФ, содержащиеся в п. 23 постановления от 30.11.2017 № 48 «О судебной практике по делам о мошенничестве, присвоении и растрате», относятся в целом к характеристике присвоения или растраты и особенностям его предмета, что раскрывается, в том числе, с помощью указания на полномочия лица в отношении чужого имущества.

Пунктом 29 этого постановления уточняется, что отсутствует такой признак, как совершение присвоения или растраты лицом с использованием своего служебного положения, в том случае, если имели место присвоение или растрата принадлежащего физическому лицу (в том числе индивидуальному предпринимателю) имущества, которое было вверено им другому физическому лицу на основании гражданско-правовых договоров аренды, подряда, комиссии, перевозки, хранения и др. или трудового договора.

Соответственно высший судебный орган уточняет специфику предмета преступного посягательства при присвоении или растрате, совершенных лицом с использованием своего служебного положения, через ограничительное толкование полномочий специального субъекта такого преступления.

Остановимся несколько подробнее на существенных признаках предмета присвоения или растраты, совершенных лицом с использованием своего служебного положения, поскольку точное установление предмета преступления имеет важное, как теоретическое, так и практическое значение, и, в первую очередь для отграничения рассматриваемых преступных посягательств от смежных или сходных составов преступлений.

Как уже отмечалось предметом присвоения или растраты, совершенных ли- цом с использованием своего служебного положения, выступает чужое имущество, вверенное виновному.

А.И. Рарог отмечает, что среди криминалистов устоялось мнение, что под предметом хищений понимается не любой объект права собственности, а лишь такой, который обладает: 1) вещным признаком, т.е. имеет определенную физическую форму; 2) экономическим признаком, т.е. объективной экономической ценностью; 3) юридическим признаком, т.е. является для виновного чужим [2, с. 410,411]; [6, с.188].

Относительно имущества, отметим, что непрерывное развитие и последовательное совершенствование материальной основы общественного производства неизбежно влечет появление новых реалий, которые требуют как осмысления, так и при необходимости, нормативного освоения.

Современные базисные отношения товарного обмена носят всеобъемлющий характер и вовлекают в сферу экономического оборота все больший круг ценностей и активов, результатом чего и явилось нормативное изменение понятия имущества, поскольку по поводу благ определенного типа сформировалась ощутимая общественная потребность в их особом регулировании.

Так, федеральным законом от 18.03.2019 № 34-Ф3 «О внесении изменений в части первую, вторую и статью 1124 части третьей Гражданского кодекса Российской Федерации»[3] в ст. 128 ГК РФ были внесены изменения, непосредственно касающиеся имущества, как объекта гражданских прав.

Законом также внесены изменения и в ст. 160 ГК РФ, согласно которым урегулирована электронная форма сделки.

Соответственно, согласно гражданского законодательства на сегодняшний день к имуществу относятся вещи (включая наличные деньги и документарные ценные бумаги), иное имущество, в том числе имущественные права (включая безналичные денежные средства, бездокументарные ценные бумаги, цифровые права).

Как видно в данном случае в ГК РФ нашла законодательное закрепление наметившаяся в сфере гражданского оборота в последнее десятилетие тенденция приравнивания значения и оборота прав к вещам.

В связи с этим традиционное и устоявшееся понимание предмета корыстных посягательств против собственности претерпевает закономерное развитие и

\section{3}

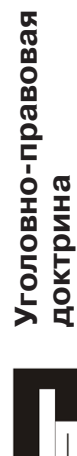


выходит за рамки обязательного овеществления в физической форме. К ранее отдельно выделяемым праву на имущество, безналичным денежным средствам добавляются такие объекты, как цифровые права.

Что касается безналичных денежных средств, как вида имущественных прав, то на сегодняшний день они достаточно часто выступают предметом преступного посягательства.

Так, например, К., обладающая в полном объеме полученной в результате исполнения своих служебных обязанностей информацией о порядке приходования денежных средств, поступавших в кассу и о порядке их инкассации, путем использования автоматизированной программы учета товарно-материальных ценностей и денежных средств «1С: Предприятие», присвоила безналичные денежные средства с расчетного счета ООО «Сеть Связной», к которому у последней, в связи с исполнением ею трудовых обязанностей, имелся доступ через программное обеспечение, установленное в рабочем компьютере.

К. В течение ноября 2018 г. умышленно отражала несоответствующие действительности сведения о поступлении от клиентов денежных средств на общую сумму 838000 рублей в кассу вышеуказанного торгового объекта в целях пополнения их электронных кошельков системы «Visa QIWI WALLET», после чего, используя программу «1С: Предприятие», производила операции по безналичному переводу денежных средств на общую сумму 838000 рублей с расчетного счета, открытого на ООО «Сеть Связной» на электронный кошелек системы «Visa QIWI WALLET», зарегистрированный на себя. Впоследствии часть похищенных денежных средств К. обналичивала через банкоматы на территории г. Лесосибирска Красноярского края, а часть использовала для безналичного расчета на его территории при оплате за товары и услуги ${ }^{1}$.

В целом и предмет преступлений против собственности и, в частности, само имущество, это широкие понятия, которые на сегодняшний день включают не только материальные овеществленные предметы, но и иные объекты гражданских прав в рамках имущества, в той части, в которой они составляют экономи-

Приговор Лесосибирского городского суда Красноярского края № 1-155/2019 от 28.05.209 по делу № 1-155/2019 (24RS0033-01-2019000788-90; 11901040007000054). URL: https:// sudact.ru/regular/doc/yUediZmic1Yj/ (дата обращения 01.09.2021) ческую ценность, имеют стоимостное выражение и подлежат денежной оценке.

Введение в круг имущества цифровых прав это адекватная реакция законодателя на современную действительность.

Безусловно, такое положение дел влияло и на правоприменение, когда фактически есть хищение, но с правовой точки зрения нет предмета посягательства ${ }^{2}$.

В преддверии законодательных новелл по цифровым правам председателем Конституционного Суда Российской Федерации В.Д. Зорькиным было отмечено, что развитие информационных технологий за два последних десятилетия ведет к формированию новой цифровой реальности, поэтому «прежнее нормативноправовое регулирование различных сфер социальной жизни нуждается в существенной модернизации», «зарождается новое право - «право второго модерна», регулирующее экономические, политические и социальные отношения в контексте мира цифр, больших данных, роботов, искусственного интеллекта»[1].

Вполне обоснованно рассмотреть возможность признания цифровых прав при присвоении или растрате, совершенных лицом с использованием своего служебного положения.

Согласно ст. 141.1 ГК РФ цифровыми правами признаются названные в таком качестве в законе обязательственные и иные права, содержание и условия осуществления которых определяются в соответствии с правилами информационной системы, отвечающей установленным законом признакам. Осуществление, распоряжение, в том числе передача, залог, обременение цифрового права другими способами или ограничение распоряжения цифровым правом возможны только в информационной системе без обращения к третьему лицу.

В п. 2 ст. 141.1 ГК РФ определен и обладатель цифрового права, которым признается лицо, имеющее в соответствии с правилами информационной системы возможность распоряжаться этим праBом.

Рассматривая далее возможность признания цифровых прав предметом присвоения или растраты отметим, что на сегодняшний день цифровые права перечислены среди объектов гражданских прав в ГК РФ наряду с безналичными денежными средствами.

\footnotetext{
2 Интересный казус имел место в Красноярске, когда у геймера отобрали виртуальное оружие на 27 тысяч рублей. См.: https://ria.ru/ incidents/20161223/1484383934.html (дата обращения 01.09.2021)
} 
К примеру, в п. 5 постановления Пленума Верховного Суда РФ от 30.11.2017 № 48 «О судебной практике по делам о мошенничестве, присвоении и растрате» указано, что «если предметом преступления при мошенничестве являются безналичные денежные средства, в том числе электронные денежные средства, то по смыслу положений пункта 1 примечаний к статье 158 УК РФ и статьи 128 Гражданского кодекса Российской Федерации содеянное должно рассматриваться как хищение чужого имущества».

В случае же присвоении или растраты, можно говорить о хищении, как безналичных денежных средств, так и цифровых прав, если виновному были вверены коды такой организации, или он обладал правом электронной подписи и т.п.

Например, лицо, используя свое служебное положение и обладая в силу последнего доступом к идентификации пользователя, вполне может совершить смарт-контракт с имуществом компании в форме цифровых прав, в результате чего как присвоить, так и растратить такое имущество. Смарт-контракты имеют распространение в банковской сфере и электронной торговле.

Основной вопрос при квалификации в таком случае возникает в критериях отграничения присвоения или растраты от хищения такого имущества путем злоупотребления доверием.

На данный момент можно кратко указать, что при присвоении или растрате в отношении цифровых прав можно говорить лишь в случае, если у лица есть правомерный доступ к таким правам и распоряжение ими входит в компетенцию его служебного положения.

Таким образом, при определении предмета присвоения или растраты следует понимать имущество более широко, выходя за рамки отнесения к нему только вещей и признавая возможность хищения иного имущества, в том числе не только безналичных денежных средств, но и цифровых прав.

\section{Литература}

1. Зорькин В.Д. Право в цифровом мире. Размышление на полях Петербургского международного юридического форума // Российская газета. Столичный выпуск. 2018. 29 мая №7578 (115).

2. Курс уголовного права. В 7 т. Т. З. Особенная часть / под ред. Г.Н. Борзенкова и В.С. Комиссарова. М., 2002. 470 с.

3. О внесении изменений в части первую, вторую и статью 1124 части третьей Гражданского кодекса Российской Федерации: федеральный закон от 18.03.2019 № 34-Ф3 // Собрание законодательства РФ. 25.03.2019. № 12. Ст. 1224.

4. О внесении изменений в постановление Пленума Верховного Суда Российской Федерации от 7 июля 2015 года № 32 «О судебной практике по делам о легализации (отмывании) денежных средств или иного имущества, приобретенных преступным путем, и о приобретении или сбыте имущества, заведомо добытого преступным путем»: постановление Пленума Верховного Суда РФ от 26.02.2019 № 1 // Бюллетень Верховного Суда РФ. 2019. № 4.

5. О судебной практике по делам о легализации (отмывании) денежных средств или иного имущества, приобретенных преступным путем, и о приобретении или сбыте имущества, заведомо добытого преступным путем: постановление Пленума Верховного Суда РФ от 07.07.2015 № 32 // Бюллетень Верховного Суда РФ. 2015. № 9.

6. Российское уголовное право. Особенная часть / под ред. В.С. Комиссарова. СПб.: Питер, 2008. 718 с

7. Уголовное право. Особенная часть: Учебник / под ред. Л.В. ИногамовойХегай, А.И. Рарога, А.И. Чучаева. 2-е изд., исправл. и доп. (автор параграфа - Рарог А.И.).М.: Юридическая фирма «КОНТРАКТ», ИНФРА-М, 2008. 800 с.

\section{References}

1. Zor'kin V.D. Pravo v tsifrovom mire. Razmyshleniye na polyakh Peterburgskogo mezhdunarodnogo yuridicheskogo foruma // Rossiyskaya gazeta. Stolichnyy vypusk. 2018. 29 maya №7578 (115).

2. Kurs ugolovnogo prava. V 7 t. T. 3. Osobennaya chast' / pod red. G.N. Borzenkova i V.S. Komissarova. M., 2002. 470 s.

3. O vnesenii izmeneniy v chasti pervuyu, vtoruyu i stat'yu 1124 chasti tret'yey Grazhdanskogo kodeksa Rossiyskoy Federatsii: federal'nyy zakon ot 18.03.2019 № 34-FZ // Sobraniye zakonodatel'stva RF. 25.03.2019. № 12. St. 1224

4. O vnesenii izmeneniy v postanovleniye Plenuma Verkhovnogo Suda Rossiyskoy Federatsii ot 7 iyulya 2015 goda № 32 «O sudebnoy praktike po delam o legalizatsii (otmyvanii) denezhnykh sredstv ili inogo imushchestva, priobretennykh prestupnym putem, i o priobretenii ili sbyte imushchestva, zavedomo dobytogo prestupnym 
putem»: postanovleniye Plenuma Verkhovnogo Suda RF ot 26.02.2019 № 1 // Byulleten' Verkhovnogo Suda RF. 2019. № 4.

5. O sudebnoy praktike po delam o legalizatsii (otmyvanii) denezhnykh sredstv ili inogo imushchestva, priobretennykh prestupnym putem, i o priobretenii ili sbyte imushchestva, zavedomo dobytogo prestupnym putem: postanovleniye Plenuma Verkhovnogo Suda RF ot 07.07.2015 № 32 // Byulleten' Verkhovnogo Suda RF. 2015. № 9

6. Rossiyskoye ugolovnoye pravo. Osobennaya chast' / pod red. V.S. Komissarova. SPb.: Piter, 2008. $718 \mathrm{~s}$.

7. Ugolovnoye pravo. Osobennaya chast': Uchebnik / pod red. L.V. InogamovoyKhegay, A.l. Raroga, A.l. Chuchayeva. 2-ye izd., ispravl. i dop. (avtor paragrafa Rarog A.I.). M.: Yuridicheskaya firma "KONTRAKT", INFRA-M, 2008. $800 \mathrm{~s}$.

ШИНКЕВИЧ Маргарита Владимировна, старший преподаватель кафедры административного права и административной деятельности ОВД Сибирского юридического института МВД России. 660131, г. Красноярск, ул. Рокоссовского, 20. E-mail: margaritavl@mail.ru

SHINKEVICH Margarita Vladimirovna, Senior Lecturer of the Department of Administrative Law and Administrative Activities of the Department of Internal Affairs of the Siberian Law Institute of the Ministry of Internal Affairs of Russia. 660131, Krasnoyarsk, Rokossovsky str., 20. E-mail: margaritavl@mail.ru. 